\title{
HIGH NATURE VALUE (HNV) FARMING AND THE MANAGEMENT OF UPLAND DIVERSITY. A REVIEW
}

\author{
Eileen O’Rourke ${ }^{1}$, Nadine Kramm²
}

Received 9 June 2011; Accepted 23 March 2012

\begin{abstract}
High nature value (HNV) farming systems play a crucial role in the conservation of biodiversity across large tracks of the European countryside. The socio-economic viability of these low intensity farming systems is in question, with many facing the stark choice of either abandonment or intensification. This review paper explores the concept of HNV farming and examines the links between grazing management and biodiversity conservation in European HNV upland environments. The paper ends with an analysis of the implications of European agricultural policy for HNV farmland, along with future trends and challenges for HNV farming systems.
\end{abstract}

Key Words: High Nature Value Farming, uplands, biodiversity, grazing management, multifunctionality.

\section{Introduction}

Contemporary European upland landscapes are the product of a long-standing relationship between natural processes and human activities. The value of such areas as repositories for biodiversity has long been recognised, yet their biological richness has been marked by a steady decline over the past half century (COM 2009; Usher and Thompson 1988). The main human-induced cause behind this is habitat degradation resulting from intensification or extensification of land use, that often occur on the same agricultural holding. While biodiversity loss is increasingly perceived as an issue of great importance for human welfare, the design of sustainable agricultural and biodiversity policies in high nature value (HNV) upland areas has been found to present considerable challenges. The chief dilemma, as pointed out by Webb (1998: 989) is that although there is a strong rationale for maintaining and enhancing cultural landscapes where they have survived, this is in fact problematic "as the agricultural economy which lay behind them no longer exists and modern agri-environment schemes are not at present an adequate substitute".

European policy has come to view low-intensity farmers as custodians of the landscape and instigators of the new multifunctional rural development model rather than as food producers. The consequence of this is that landscape and biodiversity benefits which previously arose as mere by-products of traditional farming practices are now increasingly regarded as positive externalities to be actively managed and paid for by the public sector (Cooper et al. 2009; Vos and Meekes 1999; Green and Vos 2001; Plieninger et al. 2006). No market mechanisms exist to remunerate producers for the provision of environmental goods and services, including biodiversity and landscape maintenance. This absence of markets for public goods valued by society, often referred to as the 'missing market phenomenon' (cf. Nowicki 2004), not only

\footnotetext{
${ }^{1}$ Dr. E. O'Rourke, Department of Geography, University College Cork, Cork, Ireland; e-mail: e.orourke@ucc.ie

${ }^{2}$ Nadine Kramm, PhD. Student, Environmental Research Institute, University College Cork, Cork, Ireland
} 
legitimises but necessitates state support to secure the production of vital goods and services that otherwise would run the risk of being underprovided. The double dilemma for both scientists and policy makers, is how to 'engineer' the environmental goods and services that hitherto were merely by-products of traditional farming systems; and how to create a market for nature conservation?

It has become widely acknowledged that European farmers of the $21^{\text {st }}$ century are expected to produce more than food and fibres. The so called European Model of Agriculture (EMA) agreed in the Agenda 2000 reform package to the Common Agricultural Policy (CAP), embraces both market liberalization and multifunctionality as its leading concepts. What is largely lacking, however, as Bignal (1998) reminds us, is a public debate on what we mean by and expect from the European Model of Agriculture, so that this can be translated into specific, measurable and defensible environmental and social goals. There is also uncertainty surrounding the concept of 'public goods' as a vehicle for integrating biodiversity and other ecosystem services into agricultural and other policies (Cooper et al. 2009; Redford and Adams 2009; Poux 2010a).

Agri-environment schemes provide assistance for the maintenance of traditional cultural landscapes in some areas, but their impact has so far been described as rather narrow (Kleijn and Sutherland 2003; Primdahl et al. 2010; Finn et al., 2009; Green and Vos 2001; Feehan et al. 2002). Besides, as observed by EFNCP et al. (2010: 10) "agri-environment payments are calculated on the basis of income forgone and additional costs, and so in theory cannot pay for the continuation of existing farming systems, even if this delivers significant benefits". Concerns are currently being raised about the negative effects agricultural restructuring will have on high nature value farming in disadvantaged areas where there is no economic incentive to produce for farm prices below production costs (Coordination Paysanne Europeenne 2003).

It is within this context that traditional High Nature Value (HNV) farming systems have caught the attention of scientists, conservationists and politicians. Accepting that low-intensity farming systems are beneficial, even essential, for biodiversity conservation in semi-natural landscapes (Rundlof et al. 2008; EEA 2004; Critchley et al. 2003; Chamberlain et al. 2000), it then becomes necessary to understand how these farming systems work and how they can be maintained into the future. The aim of this review paper is firstly to explore, via the literature, the concept of high nature value farming, and secondly to examine the links between grazing management and biodiversity conservation in European HNV upland environments. We start with an overview of the HNV concept, followed by an analysis of the biodiversity impacts of traditional HNV grazing practices on semi-natural European uplands, and end by positioning the debate within the current multifunctional agricultural model.

\section{The High Nature Value Farming Concept}

The term High Nature Value (HNV) farming is used to describe broad types of farming that, because of their characteristics are 'inherently high in biodiversity' (EFNCP et al. 2010:5). Typically these are traditional low intensive farming systems, usually found on poorer land with high levels of semi-natural vegetation (cf. Beaufoy 2008; Beaufoy and Cooper 2009). Since the 1990s there has been a growing recognition that the conservation of biodiversity in Europe cannot be met solely by protecting particular habitats, species or areas, such as under Natura 2000; we must also maintain the low intensive farming practices that co-create such landscapes and biotopes. HNV farming systems tend to generate low incomes from the market and also they usually receive the smallest CAP 'Pillar 1' income payments. The pressure is therefore on HNV farmers to either abandon or intensify their farming system in the search for better returns - both paths are major causes of biodiversity loss and of the decline of other ecosystem services, especially associated with extensive livestock systems. Traditional, low-intensive farming systems are found throughout the European Union where they exist in a variety of environments, climatic conditions, economic contexts and production systems. However, they tend to be concentrated in less productive, peripheral areas, such as southern and eastern Europe and in mountainous regions, and they largely overlap with less favoured areas (LFA). The European Environment Agency (EEA) and the European Commission (JRC) estimate that about $30 \%$ of farmland in the EU may be HNV farmland, and in several countries the figure is considerably higher (Paracchini et al. 2008; EEA 2004, [see Figure 1]). The diversity in HNV farming systems has arisen out of a fundamental requirement to suit available resources and 
local social needs, and stands in stark contrast to the industrialised agricultural sector that is marked by homogeneity of livestock breeds, resource use and management systems (Beaufoy 2008; Beaufoy et al. 1994; Bignal 1998, 1994; Bignal \& McCracken 1996, 2000; Luick, 1998; Baldock et al. 1996).
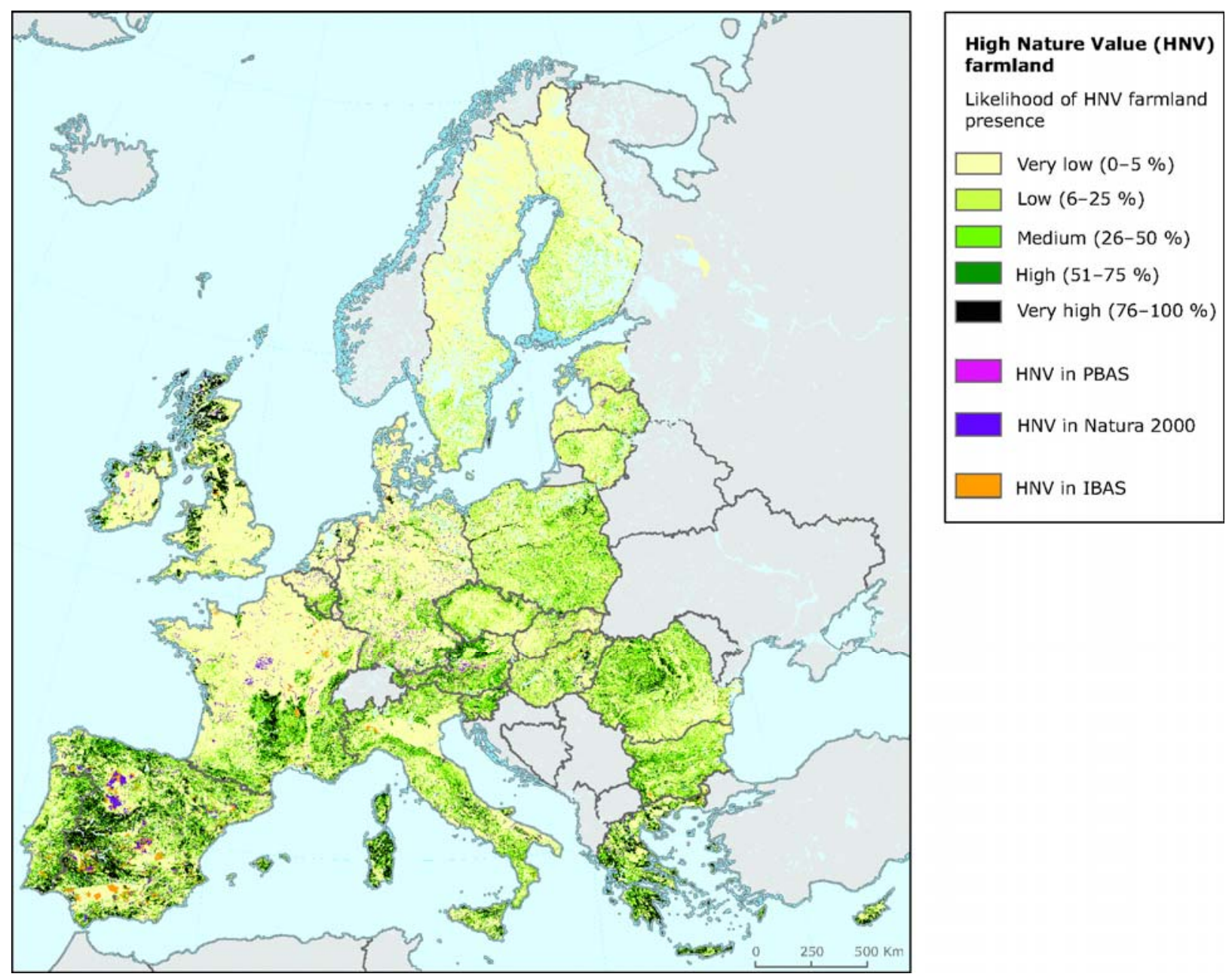

Fig 1. Potential HNV Farmland in Europe, based on Corine Land Cover (Source: European Environment Agency (2010) (www.eea.europa). [Note: PBAs = Primary Butterfly Areas; IBAs = Important Bird Areas]

The concept of High Nature Value (HNV) reflects in itself a paradigm shift in European policy away from production towards public goods provision. HNV farming commitments were established first in the 1998 EU Biodiversity Strategy (COM 1998), with the explicit objective "to promote and support low-intensity farming systems..." (Beaufoy 2008:3). However, a fundamental shift in CAP funding away from intensive farming to provide support for these beneficial land uses and the resultant public goods, has not yet occurred. Alternatively, HNV farming is frequently criticised from a global food perspective. As Poux (2010b:4) put it; "It is understood as a selfish, wealthy European vision, with citizens able to pay for nice 'gardened' landscapes and quality food, forgetting the poor both inside and outside Europe". It is estimated that we will require at least a $40 \%$ increase in global food production to feed the projected 9 billion people that will inhabit the Earth in the coming decades (Vidal 2010). The question frequently posed is: Can we afford such a policy? Given that most food is produced on the fertile soils that cover just $11 \%$ of the global land surface, the polarisation between agricultural intensification and extensification, or even abandonment, is currently a well established trend with major environmental and social consequences. If the European Union is serious about its expresses commitment to halting biodiversity loss by 2010 , (a target already missed) and maintaining a lived countryside, as exemplified in the Cork Declaration (1996) and in Agenda 2000, perhaps the pertinent question, in response to Poux's above observation is: How can we not afford such a policy? 
High nature value farming systems still lack a precise and generally applicable definition as they tend to be difficult to specify in quantitative terms (Beaufoy and Cooper 2009; Baldock 1998), yet a number of recurrent themes can be identified that are important for understanding the functional role of such farming systems. According to Beaufoy and Cooper (2009:6) the key core characteristics of HNV farming and around which a set of impact indicators can be set are:

1. Low intensity farming characteristics - high biodiversity, low intensive use of machinery, fertiliser and pesticides and/or high densities of grazing livestock.

2. Presence of semi-natural vegetation - such as unimproved grazing land and traditional hay meadows.

3. Diversity of land cover - 'mosaics' of land cover and land use.

Beaufoy (2008:9) emphasised that HNV farmed areas are not equivalent to Less Favoured Areas or Natura 2000 sites, although considerable overlap can be expected, as they are delineated on very different criteria. Neither is the objective to produce HNV maps excluding or including farms for the purpose of HNV support payments. Rather by using farm level indicators, adopted to local conditions, support payments could be directed towards HNV farms without the need to produce maps (Beaufoy 2008; Beaufoy and Cooper 2009)

Hopkins (1991) stated that HNV farming comprises of system's which are heavily dependent upon vegetation composed of wild plant species for grazing or fodder production. This applies to farmland that has not been fundamentally altered through drainage or the large-scale improvement that became a defining feature of modern agricultural systems over the past half century. The presence of natural and climatic constraints that inhibit the mechanisation and intensification of farming, in for example the uplands, not only restricts the percentage of land available for utilisation, but also results in a diverse mosaic of biodiversity rich semi-natural vegetation, interspersed with other types of land cover, such as, varied field margins, exposed rock, water bodies, woodland and scrub, offering a rich combination of habitats (Brak et al., 2004). The generally low levels of external inputs of fertiliser and agro-chemical on semi-natural vegetation create conditions that are essential for the survival of numerous plant species that are intolerant of high nitrogen and phosphate levels (Beaufoy et al., 1994). At the same time, the low nutritional value of semi-natural vegetation severely restricts the land's carrying capacity and sustains a lower livestock density with accordingly low inputs of organic nutrients. Under these circumstances, grazing pressure can only be sustained for limited periods of time and herbivores must be frequently moved on to another area. This process leads to high structural heterogeneity and diversity of vegetation being of benefit to many birds and invertebrates (Baldock et al. 1996; Fuller 1996).

Within HNV farming systems, use is frequently made of hardier, often regional livestock breeds of great genetic diversity that are well adapted to local environmental and climatic conditions, and can survive largely on rough vegetation with little concentrate feeds. While typically resulting in a low yield per hectare and being of limited contemporary market value, Aich and Waterhouse (1999) comment that the utility of such grazers goes beyond obvious economic concerns as they are capable of not only delivering important environmental services, but also of converting low-quality resources to high quality protein (meat and milk) and a multiplicity of other products including wool, hair, hide and dung.

While the majority of studies focus their attention on ecological and economic aspects of high nature value farming systems, an integrated systems perspective requires the inclusion of social principles. In this context, Baldock et al. (1996) cites the importance of long-established, often labour intensive management practices, such as transhumance, shepherding, hay-making and controlled burning. The long periods of stability and continuity in traditional management techniques, contribute to enhancing the structural diversity of vegetation. The flip side of this is that opportunities for change or agricultural adjustment may be impeded by traditional attitudes, fragmented holdings or the inability to move assets to different uses (MacDonald et al., 2000; Luick, 1998). HNV farming systems are often intended to meet individual needs rather than maximising economic profit (Konold 1998). An important social factor contributing to the overall functioning of HNV farming systems is the principle of multiple uses, denoting the interaction between public, common and private land use that is often found in remote and marginal areas, where traditional farming systems tend to persist. These systems have frequently developed to 
accommodate a multiplicity of interests and translate into a diverse mosaic of different land use types, necessitated by the topography and climate of an area, and its mixture of habitats (Berkes and Folke, 1998; Short, 2000; Kissling-Naef et al., 2002). These traditional farming systems were inherently multifunctional, before it became a fashionable policy term. Ironically, they are also the ones under the greatest risk of abandonment today.

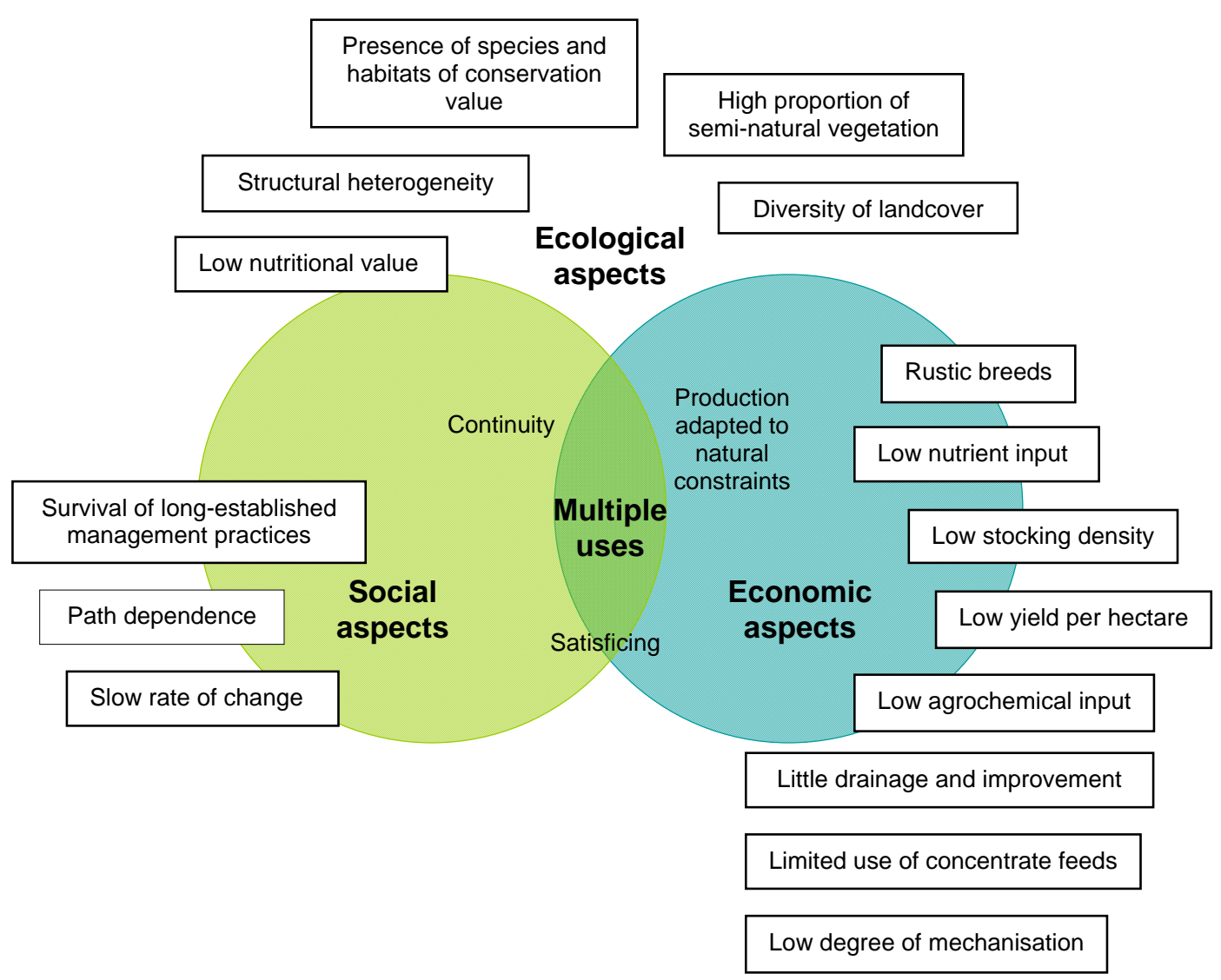

Fig 2. Conceptual Representation of HNV Farming Systems (Source: Kramm, 2009).

Figure 2, shows how the ecological, economic and social aspects of high nature value farming systems can be integrated within a single conceptual framework. In the next section we will examine in more detail the application of this model within the context of grazing management and biodiversity conservation in European upland environments.

\section{Biodiversity Conservation and Grazing Management in European HNV Uplands}

\subsection{The impacts of grazing on vegetation}

Evans et al. (2006) reminds us that the pattern of grazing in European uplands has never been static, and has always been an agent of profound ecological change. A considerable body of literature deals with the ecological impacts of livestock grazing. Dennis $(2003,2004)$ and Evans et al. (2006) discuss its function in creating and maintaining open upland habitats, presenting ample evidence on the impacts of grazing on bird life, habitat structure as well as floral and invertebrate abundance and diversity (see also Grant and Armstrong 1993; Fuller 1996; Welch 1998). In the absence of grazing and other traditional management practices, as remarked by Thompson et al. (1995) 'below the tree line all but the wettest blanket bog would naturally 
succeed to trees'. Through selective feeding, grazing herbivores play an important role in determining the presence and relative abundance of species in a habitat (Swales et al. 2004; Rook et al. 2004, Alban et al. 2007; O'Rourke 2006). Studies have shown that both under and over grazing adversely affect upland biodiversity (Grant and Armstrong, 1993; White and Wadsworth, 1994; Thompson et al., 1995; Hester, 1996; Ball et al. 1982; Kramm et al. 2010; Grimes 1973, 1979). Figure 3, suggests that an intermediate level of grazing gives rise to the highest plant diversity. This opposes the older idea that diversity is highest in undisturbed ecosystems.

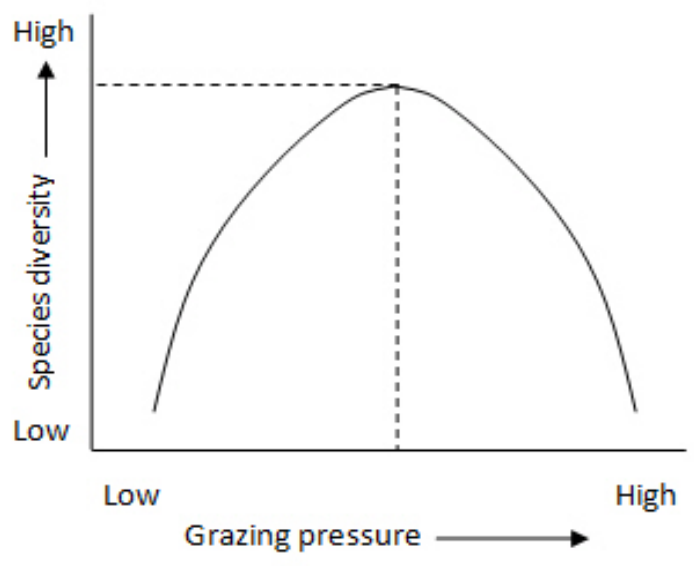

Fig 3. Sheep grazing pressure and plant species diversity after Grime - 1979.

The theory underlying much of this work is based on the widespread recognition that vegetation systems have an inherent inclination towards a single climax state with grazing working in the opposite direction of the successional tendency. Hence the assumption that grazing pressure can be made equal and opposite to the successional tendency, producing an equilibrium in the vegetation at a set stocking rate. The principal task then becomes one of defining, typically through modelling, the stocking rate that produces the desired vegetation state for a given system by striking a balance between the natural successional process and the grazing pressure needed to arrest it. If the stocking rate is increased, the system moves away from its climax state, if it is relaxed it moves closer towards it (see Figure 4).

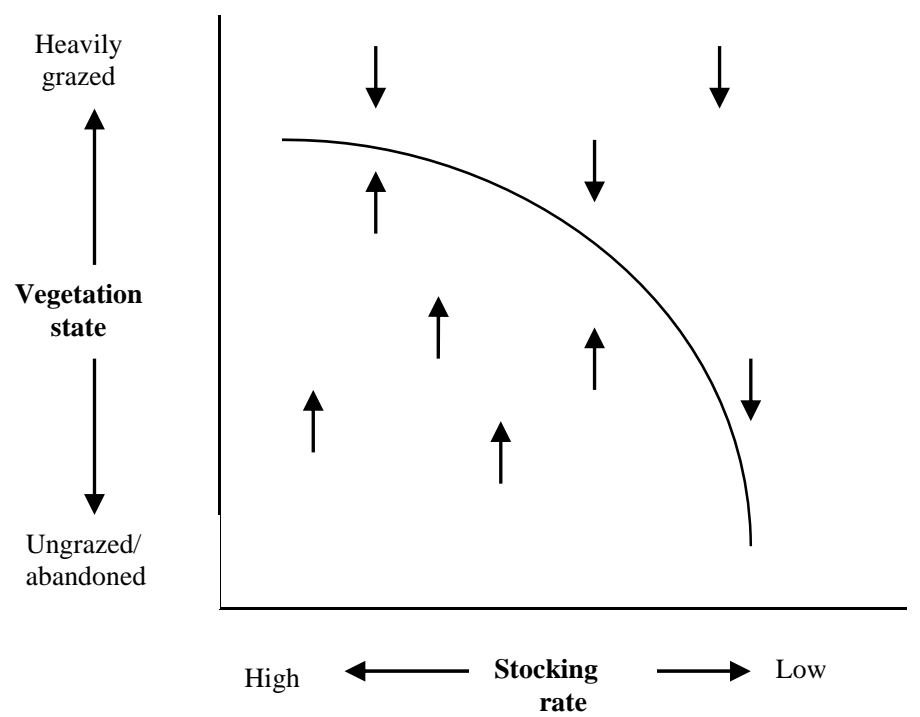

Fig 4. Relationship between stocking rate and vegetation condition: Adapted from Westoby et al. (1989: 267).

The concept of carrying capacity, translated into prescribed stocking rates, is frequently the principal tool under any given grazing management objective. There is, however, increasing evidence that such natural science attempts to deal with upland management by prescribing optimal grazing strategies is problematic (Riedel et al. 2007; Hanley et al., 1996). While stocking 
density has an important role to play, future research will have to go beyond such an approach to gain a deeper understanding of the underlying social, economic and ecological processes rather than solely focus on their outcomes.

\subsection{Grazing for Conservation}

Rather than using the sole indicator of stocking rate, the impact of grazing on the uplands is determined in large part by type or breed of livestock, time of year, length of grazing periods, herd or flock size as well as animals' age, sex and their spatial location in the landscape. Sheep tend to choose a high percentage of their diet among preferred plant species that significantly affects the floristic diversity of vegetation communities (Brak et al., 2004; Rook, 2004). Similar to cattle, they lack upper incisors and are thus unable to cut their food, yet they can bite closer to the ground than either cattle or horses (Swales et al., 2004). As a result, the preferred grasses become rapidly depleted in densely stocked areas. In the case of large, unfenced areas under a low stocking regime, however, sheep tend to congregate in places with better quality forage while poor vegetation becomes tall and unpalatable. Heather, in particular, can become leggy and degenerate in the absence of grazing. Controlled burning then becomes necessary to rejuvenate it and enhance the nutritional value of young shoots (Brak et al., 2004). It is important to consider that the response of heather to fire is highly variable, depending on the type of habitat burnt and the age of the heather as well as the temperature and duration of the fire (Fielding and Haworth 1999). Traditional practices like burning have an important bearing on the environmental effects of sheep grazing in upland areas.

There is ample evidence in the literature that the impact of cattle grazing differs significantly from that of sheep. Gordan and lason (1989) specify how, owing to their larger mouth parts and lower metabolic requirements, cattle are less selective in their feeding than sheep and can exist on forage of lower nutritional value. Cattle walking through high vegetation, for example, disturb invertebrates that are vital food sources for birds and bats. At the same time they provide important corridors for a number of small mammals as well as for moorland and woodland birds. In particular, they facilitate the movement of broods of young birds during the breeding season (Fuller 1996; Bignal and McCracken 1996). Cattle dung is not only nutrient rich but also supports a range of invertebrates that birds and small mammals prey on. This is well illustrated by Swales et al. (2004) who notes that one adult cow produces around four tonnes of dung a year which supports approximately $25 \%$ of her own body weight in invertebrates. Mixed grazing systems of cattle and sheep are widely recognised as being the best management regime in the promotion of upland biodiversity, as it leads to more diverse vegetation supporting a greater number of plants and animals, than grazing by a single type of livestock (English Nature 2001). One must also acknowledge the difference in foraging behaviour between rustic and improved sheep and cattle breeds, and their suitability to the rigors of upland environments (Evans et al. 2006; Albon et al. 2007; Luick 1998).

The impact of grazing is often long-lasting, what has been ascribed to the phenomenon of landscapes having a memory (Hanley et al. 2008; Burel and Baudry, 2003; Dodgshon and Olsson 2006). Hill et al. (1992) reporting on the findings of a Welsh case study that showed how high grazing pressure may hinder the re-establishment of heather moorland after as much as 12 years of protection, while grassland containing a mosaic of heather and bilberry plants can under moderate grazing pressure succeed into dense heather moorland after 14 years of protection (see also Swales et al., 2004). This also points towards the importance of not just spatial but also temporal scales in the assessment of biodiversity, as well as the difficulty of setting baseline biodiversity targets (e.g agri-environment policies), since current indicators may reflect past rather than present grazing and management practices.

When considering the environmental and biodiversity impacts of livestock grazing, it is important to also acknowledge the influence of a range of abiotic factors (like climate, nutrient supply and drainage) and how they combine with biotic factors to create conditions impacting on function, structure and diversity of the vegetation. In addition, grazing has consequences for the microclimate of the soil and sod. Changes in these conditions are known to affect seed germination and the establishment of species of grass, herbs and woody plants, especially when interacting with moisture content and locally available nutrients (Brak et al., 2004). This complexity renders it rather difficult to distinguish which factor is of greatest consequence, with 
Kuiters (2002) commenting that conclusions regarding the effects of grazing tend to be assumptions rather than the sum of substantial factual evidence.

From the above discussion on upland grazing it is apparent that management for biodiversity is highly complex and context dependent, and there is a constant trade-off between conservation and livelihood outcomes. Neither, are interpretations of biodiversity change always unambiguously positive or negative (McMahon et al. 2010; Sullivan et al. 2010; MacDonald et al. 2000). It is unlikely that any one management type will provide everything required by all species. Paying due attention to important contextual variables and how they influence optimality is therefore critical. To the extent that there is variation in social, economic and ecological systems, a much more flexible approach to conservation is required. In this sense, Bignal (1998) suggests that setting target limits of tolerance for a system, rather than defining optimum conditions for some of its components' should be the objective of integrated ecological-economic management. Instead of prescribing stocking rates, such an approach would favour policies focused on avoiding thresholds and monitoring the sum of capital stocks (i.e. natural and other capital) by looking at the functional parameters of a system's joint ecological, agricultural, and socio-economic components.

To date, little research effort has been devoted to identifying potential solutions that combine biodiversity-sensitive farming with socio-economic policies that help to improve livelihood outcomes for livestock owners. This, however, is imperative in view of the emerging multifunctional agricultural regime that is based on a novel relationship between modern agriculture and rural society, and is no longer defined by a single production-oriented goal (Kristensen et al., 2004).

\section{The Inclusion of Human needs into HNV Conservation Grazing Issues}

Sheep husbandry in Europe traditionally provided subsistence farmers with multiple important products such as meat, milk, wool and skins. Until relatively recently, the main product of extensive sheep farming in northern Europe was wool. Reduced demand due to increased use of synthetic fibres led to a gradual and ongoing downward trend in wool prices beginning in the late 1960s. The consequence was a movement of resources into the production of other commodities. Meat is now the main income-generating product of European sheep farmers whereas wools and skins, on the other hand, have lost their economic importance. Luick et al. (1998) observed that shearing costs often exceed revenues generated by selling wool.

Contemporary sheep keeping is therefore facing difficulties; and current market prices for the sale of meat lambs cover little more than production costs, and a large part of sheep farmers' income is made up of subsidies (O'Rourke and Kramm 2009; Winter et al. 1998). The continued existence of extensive sheep keeping therefore seems to be dependent on the production of high quality meat lambs sold for premium prices, possibly to niche markets. This, however, poses problems for HNV farmers as quality meat production necessitates a complete re-orientation of production systems that are geared towards wool production. Luick (1998:980) illustrates the dilemma thus: 'The large flocks of previous times needed 'something' to eat throughout the year, and the poor diet that grew on the... mountains was just enough for their maintenance. The growth rate of the lambs was, of course, very limited. In contrast, a modern and profitable working shepherd cannot make a living (only) on the uplands with their high nature value, because the production of marketable lambs requires better quality grazing. This leads to the limiting point of modern sheep keeping, which is the difficulty of finding the necessary good grazing at low cost.'

The isolation and natural handicaps often experienced in marginal upland areas reduce competitiveness and limit the scope for technical and structural adaptation. As previously stated, the inhabitants of such areas are often less adaptable due to age, lacking skills and opportunities, risk aversion and deep-rooted tradition (see also Walther, 1986; Campagne et al., 1990; MacDonald et al., 2000). Perhaps the most trying problem facing such areas over the medium to long term, however, is the scarcity of farm successors to be accounted for by a combination of declining incomes, a shortage of suitable employment opportunities to supplement farm incomes, long working hours and low social status associated with traditional farming. Case study research on the uplands in SW Ireland, found that from a sample of 80 hill 
sheep farmers, only $19 \%$ made a viable living solely from farming (but on average farming constituted $61 \%$ of family farm income), and almost $50 \%$ did not have a designated successor (O'Rourke and Kramm 2009).

\subsection{Land Abandonment}

The abandonment of agricultural land and traditional farming practices is widely recognised as one of the main threats facing European HNV mountain areas, (cf. DLG, 2005; Conti and Fagarazzi 2006; MacDonald et al., 2000; Gellrich et al., 2007; Baudry 1991). In spite of being the outcome of a rational economic decision at the farm household level, land abandonment is undesirable from both a social and an environmental point of view; as vegetation succession leads to species-poorer and more homogeneous vegetation types. As observed by Plieninger et al., (2006), the key problem with semi-natural landscapes is their inherent instability, rendering them dependent on a certain degree of human intervention. To date, there has been little formal research on the connection between land abandonment and local socio-economic impacts. Overall, the concentrated loss of agricultural land weakens the economic base of communities as the land loses its production function (Correira, 1993; Burel and Baudry, 1995; MacDonald et al. 2000). The knock-on economic effects of land abandonment can be even more serious, if the areas affected are important for nature tourism and recreation, as scrub encroachment reduces the attractiveness of the landscape (DLG, 2005).

\subsection{The Drivers of Change}

In what was one of the first comprehensive studies on an increasingly topical issue, Baldock et al. (1996) looked at several European countries and found areas with physical and socioeconomic obstacles to modern agriculture to be most vulnerable to the various forms of land abandonment. Steep and terraced slopes wet areas without drainage and areas distant to roads and construction zones were among the main factors identified as increasing the likelihood of abandonment. Turenne (1991) argued, however, that the presence of environmental constraints on its own failed to satisfactorily explain the current transformations of landscapes. He argued that land abandonment needed to be placed within the context of larger changes affecting European farming, including the move towards non-agricultural use of land, changing labour markets and declining relative prices for agricultural products (see also DLG, 2005). This is largely consistent with the findings of Strijker (2005), who describes off-farm opportunities which effectively increase the opportunity cost of agricultural labour - as the main determinant of land abandonment. Similarly, earlier studies by Walther (1986) have singled out the presence of significant income disparities between agricultural and non-agricultural jobs, as well as the inability to modernise land use and road infrastructure developments due to the physical constraints of upland areas, as the most important drivers of land marginalisation.

While rural depopulation is generally assumed to be an important contributor to land abandonment, Gellrich and Zimmermann (2006) also describe immigration and speculation on land value as an important contributory factor. In essence, the hypothesis underlying the majority of studies is that land where cultivation costs are not covered by yields seems to be favoured in terms of abandonment (see also Gellrich et al., 2007; Mottet et al., 2006), with most work undertaken to date remaining firmly anchored in a rational choice theoretical framework. In case study work in the Irish uplands O'Rourke and Kramm (2009) found that abandonment and intensification frequently occurred on the same farm. In an attempt to reconcile sheep farming with off-farm work, many hill farmers had simplified their farming system, concentrating production around reclaimed 'green land' and effectively abandoned inaccessible parts of their farm, including the high uplands.

An investigation by Grinfelde and Mathijs (2003), who conducted an econometric analysis of farmers' choice regarding land abandonment in Latvia, revealed that short and long-term farm management decisions, farm income, land price, social capital, personal characteristics and the physical conditions of land all have a significant effect on the amount of land abandoned. These findings somewhat refute the results of earlier studies by implying that the low profitability of farming and the low quality of the land, both typically mentioned as the key reasons for land abandonment, are not the sole explanation. Indeed, as argued by Grinfelde and Mathijs (2003), land abandonment seems to be part of a more complex set of factors related to 
the management of a farm business, non-economic preferences, avoidance of economic risk, uncertainties and path dependencies all of which are easily overlooked when employing models based purely on the assumption of utility-maximisation. The decision to continue farming marginal land in a certain manner is not only based on economic viability; farmers have been found to continue farming even if this is not the case. The strong preference for farming as a way of life, the maintenance of family tradition, the value of living in a rural area and the lack of gainful alternatives for land, machines, buildings and labour are all known to play an important role in keeping farmers on the land (Strijker, 2005; Potter and Lobley 1998). And yet, apart from a few notable exceptions, little research effort has been devoted to revealing the underlying attitudinal and non-economic forces that cause land use to change.

\section{European Agriculture under Transformation and the Implications for High Nature Value Farmland}

European agriculture has undergone fundamental restructuring since World War II, and the emergence of the Common Agricultural Policy (CAP) in 1957. Having gone through a long period of production maximisation and guaranteed price support, to over production and the imposition of quotas under the 1992 McSharry reforms, to today's so called 'bi-polar' (Potter and Tilzey, 2005) agricultural policy, defined by both intensification and marginalisation. A comprehensive policy review embracing multifunctionality as the leading concept of the European Model of Agriculture (EMA) was agreed in the Agenda 2000 reform package to the CAP. The principle instrument of the 2003 Mid Term Review (MTR) of the CAP was the introduction of a 'single farm payment' (SFP) for EU farmers from January 2005. Fully decoupled from production volumes, this payment provides the basis for a switch from price support measures to direct payments for farmers (based on the support payments received during a reference period (2000-2002), and area support. As such, its aim is to encourage a more liberalised market-oriented farming sector by giving farmers the freedom to produce what is demanded by world market. Blacksell (2010:6) reminds us that; "One of the most important insights into this duality of intensification and marginalisation is that they are actually two sides of the same coin: investment and development in one area can lead to abandonment and decline in another'. An estimated 56\% of Europe's utilised agricultural area (McDonald 2000), falls within the 'Less-Favoured-Area' (Regulation 950/97 - now referred to as Natural Handicap), which includes a substantial amount of HNV farmland, that cannot compete with more favourable areas in terms of food production. Nor can they buffer the inevitable global market price fluctuations. The MTR reorients such farmers away from production incentives towards the so called Second Pillar of the CAP - concerned with rural development and countryside maintenance, including biodiversity conservation and agri-environment schemes. It is important to remember, that of the current CAP budget of approximately €53bn, over €40bn are spent every year on 'Pillar 1' income payments to farmers (Blacksell 2010). It has been argued that much of the money of 'Pillar 1 goes to farms that are commercially viable without income payments. As payments to Europe's more productive farmers are due to be phased out after 2013, it is, as argued by Beaufoy (2008:2), important to have clearly identified the types of farming that still need and are justified in receiving public support.

Along with the EMA another term that has crept into CAP terminology is the notion of 'rural postproductivism' or the 'post-productivist countryside, defined as an antithesis to the former 'productivist' ethos. Post-productivism has emerged as a new framework for describing the realignment of the agricultural sector within the wider socio-economic transformations of the European countryside (cf. Marsden, 1999; Marsden et al., 2002; Wilson, 2001, 2007; Murdoch et al 2003; van der Ploeg). While the literature on post-productivism seems to suggest an alternative evolutionary pathway for the European countryside based on more diverse landbased activities, such as recreation, tourism, niche food markets, biodiversity conservation and the provision of other environmental services, along with a decline of the traditional family farm, a strong critique of the latter has emerged in parallel. Morris and Evans (1999:352), for example, describe the concept as a 'myth', while Evans et al. (2002: 328) go as far as alluding to it as a 'false blind alley'. The reasoning against the notion of a post-productivist countryside is diverse, but generally rests on the observation that farmers are largely unaware of its existence, with Lobley and Potter (2004:500) noting a remarkable lack of "empirical evidence suggesting 
that a shake out of farmers or land is under way or in any way being planned by farmers themselves". Walford (2002, 2003), for instance, found that the trend towards farm intensification and specialisation continued in southeast England and that although many farm households participated in agri-environment schemes, there was little conclusive evidence as to whether their behaviour had changed in the direction of post-productivism. Evans et al. (2002) express similar scepticism about the degree to which currently observable patterns match the vision of a post-productive countryside by concluding that if post-productivism involves the reversal of productivist processes; then there is little evidence for it. Selfa et al. (2010:596) observe that there are more continuities than ruptures with past practices to be found in the contemporary multifunctional countryside, and that many current practices should be seen more accurately as 'coping or survival strategies' in response to the new conditions facing farmers. Many farmers continue to hold productivist values while taking advantage of incentives for post-productivist farming practices (Wilson 2001). However, restrictions associated with cross-compliance requirements along with the implementation of the Nitrates, Habitats and Water Framework Directives, are arguably all part of the post-productivist ethos, and they affect the majority of farmers. The evidence for agricultural multifunctionalism on the ground is weak (Van Huylenbroek et al. 2007; Dufour, 2007; O'Rourke and Kramm 2009). It is ironic that the uniqueness of many HNV areas lies in their inherent multifunctionality, yet in the absence of better integration of farm households into the rural economy, they remain heavily dependent on agricultural support. The longer-term consequences of removing the obligation to produce remain to be seen, but there are fears that de-coupling involves a greater risk of abandonment in marginal areas characterised by physical disadvantage, low yields and high transport and labour costs.

\section{Conclusions}

Traditional HNV extensive farming systems and their associated landscapes and biodiversity form complex systems whose social, economic and ecological components cannot be viewed in isolation. It was argued that the currently observable trend of polarisation in land use characterised both by conversion of low-intensity farming systems to intensified use or abandonment of production - poses a serious threat to the biodiversity contained in seminatural European landscapes, with the uplands being a case in point. Recent changes in the CAP, leaving farmers increasingly exposed to the free market are the single most important drivers of change in such landscapes, yet several other factors relating to demographic and social change also have an important bearing on the future of Europe's HNV areas. Since there is no reason to assume that the pressure from market forces on traditional farmers will come to a standstill, increasing attention must be paid to market conditions to assess the future adaptation and evolution of HNV landscapes. How will marginal farmers be able to respond to increasing competitive pressure while continuing to farm in a manner consistent with the economic, environmental and social aspects of sustainability? There is also a need to see how HNV farming enterprises can be best integrated with other sectors like tourism, forestry, recreation and landscape management. As noted by Plieninger et al. (2006), mechanisms must be found and implemented so that the ecological services provided by extensive farming systems are rewarded by society, or can be linked to new economic objectives based on for local value added products, niche markets and direct sales so as to enhance the living standard of farm families.

The sustainable development of European cultural landscapes and the conservation of their biodiversity requires actively involving local land users and responding to their needs. This fact is reflected in the latest CAP reforms that make multifunctionality one of the leading concepts of the EMA, yet there is a certain potential for policy conflict. Enhancing the living conditions of marginal farmers requires integration through a broader approach to rural development in the areas concerned than has previously been the case. While the answer to many of these concerns was thought to have arrived in the new agricultural policy framework and its emphasis on agri-environment schemes, evidence shows a certain mismatch between the holistic concept of agricultural multifunctionality and the sectoral approaches used to implement it.

Part of the reason for this is the lack of disciplinary integration in empirical research on the development of HNV farming systems, taking into consideration all their interrelated 
components. This is, admittedly, a drastic change of direction away from current agrienvironment policy with its emphasis on physical management. At the same time, it is a move closer towards the integrated rural development of the Agenda 2000 debate that would allow all the environmental and economic aspects of Europe's cultural landscapes to be incorporated into an inclusive governance and management framework (Lowe and Ward, 1998; Potter and Lobley, 1998). But, as observed by Brodt et al. (2006), we cannot expect farmers to adopt management strategies whose values are inconsistent with their personal values. Far more attention needs to be given to farmer's decision making process and livelihood strategies if we are to understand why to date they have opted for off-farm work rather than multifunctional farm diversification. Jones (2008) observed that the real challenge is how to change HNV methods of farming from a necessity to something which is socially respectable and economically viable. Enrichment either via the market or via agricultural policies has yet to happen, and HNV farming remains outside the mainstream.

This gives rise to two outstanding research priorities. The first one is related to gaining a deeper understanding of how these complex HNV farming systems work. This involves being aware of the social-ecological system under consideration, as well as the contextual factors that lead to their continual evolution and adaptation. This is vital if we are to formulate policies that enable systems to self-organise in a socially acceptable way.

The second research priority pertains to finding out why marginal farmers decide to continue to farm in traditional ways. This involves identifying - on a local level - the problems, constraints and opportunities related to biodiversity-sensitive farming in multifunctional landscapes. For example, what are the effects of generational change on farm management within HNV farmland? Or, what components of the socio-economic system under consideration are of particular importance for supporting HNV landscapes into the future. Similarly, HNV indicators must not be confined solely to farming system and ecological criteria; we must understand the mentality, values and decision making process behind the quantitative indicators.

\section{Acknowledgements}

This research was funded by Science Foundation Ireland (SFI), under the Research Frontiers Programme (EEB039). We would also like to acknowledge the contribution of the rest of the 'BioUp' team: Roz Anderson, Mark Emmerson, John O'Halloran and Nick Chisholm. We are grateful to the anonymous referees for their helpful comments.

References

[1] Albon, S. D., Brewer, M. J., O'Brien, S., Nolan, A. J. \& Cope, D. (2007). Quantifying the grazing impacts associated with different herbivores on rangelands. Journal of Applied Ecology, 44(6), 1176-1187. Doi: 10.1111/j.1365-2664.2007.01318.x.

[2] Aich, A. \& Waterhouse, A. (1999). Small ruminants in environmental conservation. Small Ruminant Research, 34(3), 271-287. Doi: 10.1016/S0921-4488(99)00079-6.

[3] Baldock, D., Beaufoy, G., Brouwer, F. \& Godeschalk, F. (1996). Farming at the Margins: Abandonment or Redeployment of Agricultural Land in Europe. London/The Hague: Institute for European Environmental Policy Agricultural Economics Research Institute.

[4] Baldock, D. (1998). Indicators for high nature value farming systems in Europe. In: F. Brouwer \& R. Crabtree (Eds.), Environmental indicators and agricultural policy (pp. 121136). Wallingford: CAB International.

[5] Ball, D., Dales, J., Sheail, J. \& Heal, O. (1982). Vegetation Change in Upland Landscapes. Cambridge, UK: Institute of Terrestrial Ecology.

[6] Baudry, J. (1991). Ecological consequences of grazing extensification and land abandonment: Role of interactions between environment, society and techniques. CIHEAM - Options Mediterraneennes - Serie Seminaires, 15, 13-19. 
[7] Beaufoy, G., Baldock, D. \& Clark, J. (1994). The Nature of Farming: Low Intensity Farming in Nine European Countries. London, UK: Institute for European Environmental Policy.

[8] Beaufoy, G. (2008). HNV Farming - Explaining the Concept and Interpreting EU and National Policy Commitments. European Forum on Nature Conservation and Pastoralism Stratford-upon-Avon. http://www.efncp.org/download/EFNCP-HNV-farming-concept.pdf.

[9] Beaufoy, G. \& Cooper, T. (2009). The Application of the High Nature Value Impact Indicator 2007-2013. (Guidance document). European evaluation network for rural Development. http://ec.europa.eu/agriculture/rurdev/eval/hnv/guidance_en.pdf.

[10] Berkes, F. \& Folke, F. (1998). Linking social and ecological systems for resilience and sustainability. In: Berkes, F., Folke, C., \& Colding, J. (Eds.), Linking Social and Ecological Systems. Cambridge: Cambridge University Press.

[11] Bignal, E. M., McCracken, D. J., \& Curtis, D. J. eds., (1994). Nature Conservation and Pastoralism in Europe. Peterborough, UK: Joint Nature Conservation Committee.

[12] Bignal, E. M. \& McCracken, D. I., (1996). Low-intensity farming systems in the conservation of the countryside. Journal of Applied Ecology 33, 413-424.

[13] Bignal, E. M. \& McCracken, D. I. (2000). The Nature conservation Value of European Traditional Farming Systems. Environmental Reviews 8(3), 149-171. Doi: 10.1139/a00009.

[14] Bignal, E. M. (1998). Using an ecological understanding of farmland to reconcile nature conservation requirements, EU agriculture policy and world trade agreements. Journal of Applied Ecology, 35(6): 949-954. Doi: 10.1111/j.1365-2664.1998.tb00013.x.

[15] Bignal, E. M. \& McCracken, E. I. (1996). The ecological resources of European farmland. In: M. Whitby (ed.), The European Environment and CAP Reform. Wallingford: CAB International.

[16] Blacksell, M. (2010). Agriculture and Landscape in $21^{\text {st }}$ Century Europe: The PostCommunist Transition. European Countryside, 2(1), 13-24. Doi: 10.2478/v10091-0100002-8.

[17] Brak, B. H., Hilarides, L., Elbersen, B. S. \& van Wingerden, W. K. (2004). Extensive livestock systems and biodiversity: The case of Islay. Alterra-rapport 1100. Wageningen: Alterra.

[18] Brodt, S., Klonsky, K. \& Tourte, L., (2006). Farmer goals and management styles: Implications for advancing biologically based agriculture. Agricultural Systems. 89(1), 90105. Doi: 10.1016/j.agsy.2005.08.005.

[19] Burel, F. \& Baudry, J. (1995). Species biodiversity in changing agricultural landscapes: a case study in the Pays d'Auge, France. Agriculture, Ecosystems and Environment, 55(3), 193-200. Doi: 10.1016/0167-8809(95)00614-X.

[20] Campagne, P., Carrere, G. \& Valceschini, E. (1990). Three Agricultural Regions of France: Three types of pluriactivity. Journal of Rural Studies, 6(4), 415-422. Doi: 10.1016/07430167(90)90055-D.

[21] Chamberlain, D. E., Fuller, R. J., Bunce, R. G. H., Duckworth, J. C. \& Shrubb, M. (2000). Changes in the abundance of farmland birds in relation to the timing of agricultural intensification in England and Wales. Journal of Applied Ecology 37(5), 771-788. Doi: 10.1046/j.1365-2664.2000.00548.x.

[22] Cooper, T., Hart, K. \& Baldock, D. (2009). The Provision of Public Goods Through Agriculture in the European Union. London: Institute for European and Environmental Policy.

[23] Coordination Paysanne Europeenne (CPE) (2003). CAP Reform: 'A scandal'. (Available online at: http://www.southcentre.org).

[24] COM (1998) 42 final Communication of the European Comisión to the Council and to the Parliament on a European Community Biodiversity Strategy. 
[25] COM (2009) Composite Report on the Conservation Status of Habitat Types and Species as required under Article 17 of the Habitats Directive. Commission of the European Communities, Brussels. http://biodiversity.eionet.europa.eu/article17.

[26] Conti, G. \& Fagarazzi, L. (2006). Sustainable mountain development and the key-issue of abandonment of marginal rural areas. The European Journal of Planning, www.planum.net.

[27] Correira, T. (1993). Land abandonment: changes in the land use patterns around the Mediterranean basin. Cahiers Options Mediterraneennes, 1, 97-112.

[28] Critchley, C. N. R., Burke, M. J. W. \& Stevens, D. P. (2003). Conservation of lowland seminatural grassland in the UK: a review of botanical monitoring results from agri-environment schemes. Biological Conservation 115(2), 263-278. Doi: 10.1016/S0006-3207(03)00146-0.

[29] Dennis, P. (2003). Sensitivity of upland arthropod diversity to livestock grazing, vegetation structure and landform. Food, Agriculture and Environment 1(2), 301-307.

[30] Dennis, P., Doering, J., Stockan, J. A., Rees, M. E., Vale, J. E. \& Sibbald, A. R., (2004). Consequences for biodiversity of reducing inputs to upland temperate pastures: Effects on beetles (coleopteran) of cessation of nitrogen fertilizer application and reductions in stocking rates of sheep. Grass and Forage Science, 59(2), 121-135. Doi: 10.1111/j.13652494.2004.00412.x.

[31] DGL (2005). Land Abandonment, Biodiversity and the CAP. Utrecht: Government Services for Land and Water Management of the Netherlands (DGL).

[32] Dodgshon, R. A. \& Olsson, G. A. (2006). Heather Moorland in the Scottish Highlands: The History of a Cultural Landscape, 1600-1880. Journal of Historical Geography, 32(1), 21-37. Doi: 10.1016/j.jhg.2005.01.002.

[33] Dufour, A., Mauz, I., Rémy, J., Bernard, C., Dobremez, L., Havet, A., Pauthenet, Y., Pluvinage, J., \& Tachakérian, E., (2007). Multifunctionality in Agriculture and its Agents: Regional Comparisons. Sociologia Ruralis, 47(4), 316-342. Doi: 10.1111/j.14679523.2007.00444.x.

[34] EFNCP - European Forum on Nature Conservation and Pastoralism, Bird Life International, Butterfly Conservation Europe, WWF (2010). CAP Reform 2013: Last chance to stop the decline of Europe's High Nature Value farming? Retrieved from (www.efncp.org/high-nature-value-farmland/cap-reform-2013/).

[35] English Nature (2001). The upland management handbook. Peterborough: English Nature.

[36] European Environment Agency (EEA) (2004). High Nature Value Farmland: Characteristics, trends and policy challenges. Luxembourg: Office of Official Publications of the European Communities.

[37] European Environment Agency (EEA) HNV Map (2010). Retrieved from (http://www.eea.europa.eu/data-and-maps/figures/approximate-distribution-of-hnvfarmland).

[38] Evans, D. M., Redpath, S. M., Elston, D. A., Evans, S. A., Mitchell, R. J. \& Dennis, P. (2006). To graze or not to graze? Sheep, voles, forestry and nature conservation in the British uplands. Journal of Applied Ecology, 43(3), 499-505. Doi: 10.1111/j.13652664.2006.01158.x.

[39] Evans, N., Morris, C. \& Winter, M. (2002). Conceptualizing Agriculture: A critique of postproductivism as the new orthodoxy. Progress in Human Geography, 26(3), 313-332. Doi: 10.1191/0309132502ph372ra.

[40] Feehan, J., Gillmor, D., \& Culleton, N. (2002). The impact of the Rural Environment protection Scheme (REPS) on plant and insect diversity. Irish Journal of AgriEnvironmental Research, 2.

[41] Fielding, A. H. \& Haworth, P. F. (1999). Upland Habitats:Habitat Guide. London:Routledge. 
[42] Finn, J. A., Bartolini, F., Kurz, I., Bourke, D., \& Viaggi, D. (2009). Ex post environmental evaluation of agri-environment schemes using experts' judgements and multicriteria analysis. Journal of Environmental Management and Planning, 52(5), 717-737. Doi: 10.1080/09640560902958438.

[43] Fuller, R. J. (1996). Relationships between grazing and birds with particular reference to sheep in the British uplands. Report No. 164, Thetford: British Trust for Ornithology.

[44] Gellrich, M., Baur, P., Koch, B. \& Zimmermann, N. E. (2007). Agricultural land abandonment and natural forest re-growth in the Swiss mountains: A spatially explicit economic analysis. Agriculture, Ecosystems and Environment, 118(1-4), 93-100. Doi: 10.1016/j.agee.2006.05.001.

[45] Gellrich, M. \& Zimmermann, N. E. (2007). Investigating the regional-scale pattern of agricultural land abandonment in the Swiss mountains: A spatial statistical modelling approach. Landscape and Urban Planning, 79(1), 65-76.

Doi: 10.1016/j.landurbplan.2006.03.004.

[46] Gordin, I. J. \& Iason, G. R. (1989). Foraging strategy of ruminants: Its significance to vegetation utilization and management. MULRI Annual Report 1988-89 (pp. 34-41).

[47] Grinfelde, I. \& Mathijs, E. (2003). Agricultural land abandonment in Latvia: an econometric analysis of farmer's choice. Leuven: Centre for Agricultural and Environmental Economics. Catholic University of Leuven.

[48] Grant, S. A. \& Armstrong, H. M. (1993). Grazing ecology and conservation of heather moorland: the development of models as aids to management. Biodiversity and Conservation, 2(1), 79-94. Doi: 10.1007/BF00055105.

[49] Green, B. H. \& Vos, W. (2001). Managing old landscapes and making new ones. In: Green, B. H. \& Vos, W. (eds.) Threatened landscapes: conserving cultural landscapes. London: Spon Press.

[50] Grime, J. P. (1973). Competitive exclusion in herbaceous vegetation. Nature. 242 (5396), 344-347. Doi: 10.1038/242344a0.

[51] Grime, J. P. (1979). Plant Strategies and Vegetation Processes. Chichester: Wiley \& Sons.

[52] Hanley, N., Davies, A., Angelopoulos, K., Hamilton, A., Ross, A., Trinch, D. \& Watson, F. (2008). Economic determinants of biodiversity change over a 400-year period in the Scottish uplands. Journal of Applied Ecology, 45(6), 1557-1565. Doi: 10.1111/j.13652664.2008.01570.x.

[53] Hester, A. (1996). Overgrazing in Upland Habitats: A literature Review. Report to Countryside Council for Wales. Aberdeen: Macaulay Research/Consultancy Services.

[54] Hill, M. O., Evans, D. F. \& Bell, S. A. (1992). Long-term effects of excluding sheep from hill pastures in North Wales. Journal of Ecology, 80(1), 1-13.

[55] Hopkins, J. J. (1991). Vegetation structure and the conservation of wild plants and animals. In: D. J. Curtis, E. M. Bignal \& M. A. Curtis (eds.), Birds and Pastoral Agriculture in Europe (pp.12-18). Peterborough: Scottish Chough Study Group.

[56] Jones, G. (2008). Small Farms - major embarrassment or key to policy delivery? La Caňada, No. 22.

[57] Konold, W. (1998). Landnutzung und Naturschutz in Auen - Gegensatz oder sinnvolle Kombination. Wasser \& Boden 50, 50-54.

[58] Kissling-Naef, I., Volken, T., \& Bisang, K. (2002). Common property and natural resources in the Alps: the decay of management structures. Forest Policy and Economics 4(2), 135147. Doi: 10.1016/S1389-9341(02)00013-8.

[59] Kleijn, D. \& Sutherland, W. J. (2003). How effective are European agri-environment schemes in conserving and promoting biodiversity? Journal of Applied Ecology, 40(6), 947-969. Doi: 10.1111/j.1365-2664.2003.00868.x. 
[60] Kramm, N. (2009). High Nature Value (HNV) Farming Systems under Diverse Policy Agendas. BioUp Project Report, Department of Geography, University College Cork.

[61] Kramm, N., Anderson, R., O'Rourke, E., Emmerson, M., O'Halloran, J. \& Chisholm, N., (2010). Framing the Iveragh Uplands: A Tale of humans and nature. University College Cork.

[62] Kristensen, K., Thenail, S. C. \& Kristensen, S. P. (2004). Landscape changes in agrarian landscapes in the 1990s: the interaction between farmers and the farmed landscape. A case study from Jutland, Denmark. Journal of Environmental Management, 71(3), 231244. Doi: 10.1016/j.jenvman.2004.03.003.

[63] Kuiters, A. T. (2002). Hoofed animals in nature areas: theory and practice versus research. Vakbad Natuurbeheer, 41, 21-23.

[64] Lobley, M., \& Potter, C. (2004). Agricultural Change and Re-structuring: Recent evidence from a survey of agricultural households in England. Journal of Rural Studies. 20(4), 499510. Doi: 10.1016/j.jrurstud.2004.07.001.

[65] Luick, R. (1998). Ecological and socio-economic implications of livestock-keeping systems on extensive grasslands in south-western Germany. Journal of Applied Ecology, 35(6), 979-982. Doi: 10.1111/j.1365-2664.1998.tb00018.x.

[66] MacDonald, A., Stevens, P., Armstrong, H., Immirzi, P., \& Reynolds, P. (1998). A Guide to Upland Habitats: Surveying Land Management Impacts. Edinburgh: Scottish Natural Heritage.

[67] MacDonald, D., Crabtree, J. R., Wiesinger, G., Dax, T., Stamou, N., Fleury, P., Gutierrez, L. \& Gibon, A., (2000). Agricultural abandonment in mountain areas of Europe: Environmental consequences and policy responses. Journal of Environmental Management. 59(1), 47-69. Doi: 10.1006/jema.1999.0335.

[68] Marsden, T. (1999). Rural futures: the consumption countryside and its regulation. Sociologia Ruralis, 39(4), 501-520. Doi: 10.1111/1467-9523.00121.

[69] Marsden, T., Banks, J. \& Bristow, G. (2002). The Social Management of Rural Nature: Understanding agrarian based rural development. Environment and Planning A, 34(5), 809-825. Doi: 10.1068/a3427.

[70] McMahon, B. J., Helden, A., Anderson, A., Sheridan, H., Kinsella, A. \& Purvis, G. (2010). Interactions between livestock systems and biodiversity in South-East Ireland. Agriculture, Ecosystems and Environment. 139(1-2), 232-238. Doi: 10.1016/j.agee.2010.08.008.

[71] Miles, J., (1988). Vegetation and soil change in the uplands. In: M. B. Usher \& D. B. Thompson (eds.), Ecological Change in the Uplands (pp. 57-70). Oxford: Blackwell Scientific Publications.

[72] Morris, C., Evans, N. (1999). Research on the geography of agricultural change: Redundant or revitalised. Area, 31(4), 349-358. Doi: 10.1111/j.1475-4762.1999.tb00101.x.

[73] Mottet, A., Ladet, S., Coque, N. \& Gibon, A. (2006). Agricultural land-use change and its drivers in mountain landscapes: A case study in the Pyrenees. Agriculture, Ecosystems and Environment 114(2-4), 296-310. Doi: 10.1016/j.agee.2005.11.017.

[74] Murdoch, J., Lowe, P., Ward, N. \& Marsden, T. (2003). The Differentiated Countryside. London: Routledge.

[75] Nowicki, P. L. (2004). Jointness of production as a market concept. In: F. Brouwer (ed.), Sustaining Agriculture and the Rural Environment. Governance, policy and multifunctionality (pp.36-55). Cheltenham: Edward Elgar.

[76] O'Rourke, E. (2006). Biodiversity and land use change on the Causse Méjan, France. Biodiversity and Conservation. 15(8), 2611-2626. Doi: 10.1007/s10531-005-5402-0.

[77] O'Rourke, E. \& Kramm, N. (2009). Changes in the Management of the Irish Uplands: A case-study from the Iveragh Peninsula. European Countryside. 1 (1), 53-69. Doi: 10.2478/v10091-009-0005-5. 
[78] Paracchini, M. L., Petersen, J-E., Hoogeveen, Y., Bamps, C., Burfield, I. \& van Swaay, C. (2008). High nature value farmland in Europe. An estimate of the distribution patterns on the basis of land cover and biodiversity data. European Commission Joint Research Centre, Institute for Environment and Sustainability. Luxembourg: Office for Official Publications of the European Communities.

[79] Plieninger, T., Hoechtl, F., \& Spek, T. (2006). Traditional land-use and nature conservation in European rural landscapes. Environmental Science and Policy, 9(4), 317-321. Doi: 10.1016/j.envsci.2006.03.001.

[80] Potter, C. \& Lobley, M. (1998). Landscapes and livelihoods: environmental protection and agricultural support in the wake of Agenda 2000. Landscape Research, 23(3), 223-236. Doi: 10.1080/01426399808706542.

[81] Potter, C. (2004). Multifunctionality as an agricultural and rural policy concept. In: Brouwer, F. (ed.) Sustaining agriculture and the rural environment. Governance, Policy and Multifunctionality (pp.15-35). Cheltenham: Edward Elgar.

[82] Potter, C. \& Tilzey, M. (2005). Agricultural policy discourse in the European post-Fordist transition: Neoliberalism, neomercantilism and multifunctionality. Progress in Human Geography 29(5), pp. 581-600. Doi: 10.1191/0309132505ph569oa.

[83] Poux, X. (2010a). Public goods as a vehicle for integrating biodiversity into agricultural (and other) policies: Opportunities and risks. La Caňada, 25, 5-6.

[84] Poux, X. (2010b). Why biodiversity should top the CAP reform agenda. La Caňada, 24, 24.

[85] Primdahl, J., Vesterager, J. P., Finn, J. A., Vlahos, G., Kristensen, L., \& Vejre, H. (2010). Current use of impact models for agri-environment schemes and potential for improvements of policy design and assessment. Journal of Environmental Management, 91(6), 1245-1254. Doi: 10.1016/j.jenvman.2009.12.012.

[86] Redford, K. H. \& Adams, W. M. (2009). Payment for Ecosystem Services and the Challenge of Saving Nature. Conservation Biology, 23(4), 785-787. Doi: 10.1111/j.1523-1739.2009.01271.x.

[87] Riedel, J. L., Casasus, I. \& Bernues, A. (2007). Sheep farming intensification and utilization of natural resources in Mediterranean pastoral agro-ecosystems. Livestock Science 111 (1-2), 153-163. Doi: 10.1016/j.livsci.2006.12.013.

[88] Rook, A. J., Dumont, B., Isselstein, J., Osoro, K., WallisDeVries, M. F., Parente, G. \& Mills, J. (2004). Matching type of livestock to desired biodiversity outcomes in pastures a review. Biological Conservation, 119(2), 137-150. Doi: 10.1016/j.biocon.2003.11.010.

[89] Rundlöf, M., Nilsson, H., Smith, H. G. (2008). Interacting effects of farming practice and landscape context on bumble bees. Biological Conservation, 141(2), 417-426. Doi: 10.1016/j.biocon.2007.10.011.

[90] Selfra, T., Fish, R., Winter, M. (2010). Farming Livelihoods and Landscapes: Tensions in Rural Development and Environmental Regulation. Landscape Research, 35(6), 595-612. Doi: 10.1080/01426397.2010.514043.

[91] Short, C. (2000). Common land and ELMS: a need for policy innovation in England and Wales. Land Use Policy, 17(2), 121-133. Doi: 10.1016/S0264-8377(00)00007-7.

[92] Strijker, D. (2005). Marginal lands in Europe - causes of decline. Basic and Applied Ecology, 6(2), 99-106. Doi: 10.1016/j.baae.2005.01.001.

[93] Sullivan, C., Sheehy Skeffington, M., Gormally, M. J. \& Finn, J. A. (2010). The ecological status of grasslands on lowland farmlands in western Ireland and implications for grassland classification and nature value assessment. Biological Conservation 143(6), 1529-1539. Doi: 10.1016/j.biocon.2010.03.035.

[94] Swales, V., Eaton, R., Castan Broto, V., Deane, R., Warmington, B., Parker, S., \& Rayment, M. (2004). An assessment of the impact of hill farming in England on 
the economic, environmental and social sustainability of the uplands and more widely. A study for Defra (Department for Environment, Food and Rural Affairs). IEEP, London.

[95] Thompson, D. B. A., MacDonald, A. J., Marsden, J. H. \& Galbraith, C. A., (1995). Upland heather moorland in Great Britain: a review of international importance, vegetation change and some objectives for nature conservation. Biological Conservation. 71(2), 163-178. Doi: 10.1016/0006-3207(94)00043-P.

[96] Turenne, J-F. (1991). Research approaches on landscape pattern dynamics in European rural areas. Unesco MAB programme. Options Méditerranénnes, 15, 135-138.

[97] Usher, M. B. \& Thompson, D. B. (1988). Eds., Ecological Change in the Uplands. Oxford: Blackwell Scientific Publications.

[98] Van der Ploeg, J. D. \& Renting, H. (2000). Impact and Potential: A comparative review of European rural development practices. Sociologia Ruralis, 40(4), 529-543. Doi: 10.1111/1467-9523.00165.

[99] Van Huylenbroeck, G. et al. (2007). Multifunctionality of Agriculture: A Review of Definitions, Evidence and Instruments. Living Reviews in Landscape Research, Vol. 1. pp.5-43. http://www.livingreviews.org//rlr-2007-3.

[100]Vidal, J. (2010). Soil loss threatens a hungry Earth. The Guardian Weekly, 17.12.2010, p 32.

[101]Vos, W., Meekes, H. (1999). Trends in European cultural landscape development: Perspectives for a sustainable future. Landscape and Urban Planning, 46(1-3), 3-14. Doi: 10.1016/S0169-2046(99)00043-2.

[102] Walford, N. (2002). Agricultural adjustment: adoption of and adaptation to policy reform measures by large-scale commercial farmers. Land Use Policy, 19(3), 243-257. Doi: 10.1016/S0264-8377(02)00018-2.

[103] Walford, N. (2003). Productivism is allegedly dead, long live productivism. Evidence of continued productivist attitudes and decision making in South-East England. Journal of Rural Studies, 19(4), 491-502. Doi: 10.1016/S0743-0167(03)00030-5.

[104]Walther, P. (1986). Land abandonment in the Swiss Alps: a new understanding of a land use problem. Mountain Resource Development, 6, 305-314.

[105]Webb, N. R. (1998). The Traditional Management of European Heathlands. Journal of Applied Ecology, 35(6), 987-990. Doi: 10.1111/j.1365-2664.1998.tb00020.x.

[106]Welch, D., (1998). Response of bilberry Vaccinium myrtillus L. strands in the Derbyshire Peak District to sheep grazing, and implications for moorland conservation. Biological Conservation. 83(2), 155-164. Doi: 10.1016/S0006-3207(97)00067-0.

[107]Westoby, M., Walker, B. \& Noy-Meir, I. (1989). Opportunistic management for rangelands not at equilibrium. Journal of Range Management, 42, 266-274.

[108] White, B. \& Wadsworth, R. (1994). A bioeconomic model of heather moorland management and conservation. Ecological Economics, 9, 197-207.

[109]Wilson, G., (2001). From productivism to post-productivism and back again? Exploring the (un)changed natural and mental landscapes of European Agriculture. Transactions of the Institute of British Geographers. 26(1), 77-102. Doi: 10.1111/1475-5661.00007.

[110]Wilson, G. A. (2007). Multifunctional Agriculture: A Transition Theory Perspective. Wallingford: CAB International, 384pp.

[111] Winter, M., Gaskell, P., \& Short, C. (1998). Upland Landscapes in Britain and the 1992 CAP Reforms. Landscape Research, 23(3), 273-288. Doi: 10.1080/01426399808706545. 